\title{
First standardized inventory of ants (Hymenoptera: Formicidae) in the natural grasslands of Paraná: New records for Southern Brazil
}

\author{
Weslly Franco ${ }^{1,2}$ \& Rodrigo Machado Feitosa ${ }^{1,3}$ \\ 1 Universidade Federal do Paraná (UFPR), Departamento de Zoologia (DZO0), Laboratório de Sistemática e Biologia de Formigas (LSBF). \\ Curitiba, PR, Brasil. \\ 2 ORCID: 0000-0003-2670-4527. E-mail: weslly.franco@gmail.com (corresponding author) \\ 3 ORCID: 0000-0001-9042-0129. E-mail: rsmfeitosa@gmail.com
}

\begin{abstract}
Despite the large number of studies investigating ant diversity in Brazilian biomes, no ant-related studies have been carried out in Campos Gerais, a grassland physiognomy in Paraná state. The present study is the first inventory of the ant fauna in one of the few conservation units protecting the Campos Gerais landscape, the Guartelá State Park (PEG). Sixty samples were collected from different habitats within PEG using pitfall traps. Qualitative samples of leaf litter were collected from forest fragments and submitted to Winkler extractors. In addition, manual qualitative sampling was carried out in the various physiognomies within the PEG. A total of 163 species was collected and sorted into 43 genera and nine subfamilies. Five genera and 28 species were recorded for the first time in the state of Paraná. Out of these, 17 species were also recorded for the first time in the Southern Region of Brazil and two were recorded for the first time to the country. The significant species richness in the PEG and the high number of new records is a strong sign of this ecosystem's potential to reveal taxonomic novelties. These results suggest that PEG, and the Campos Gerais as a whole, should be the target of greater conservation efforts to preserve native remnants.
\end{abstract}

Keywords. Diversity; Survey; Campos Gerais; Distribution; Taxonomic Novelties; Conservation.

\section{INTRODUCTION}

Ants are highly abundant and diverse around the world, on both local and regional scales, and are extremely important economically and ecologically (Davidson et al., 2003; Wilson \& Hölldobler, 2005; Ward, 2007; Guénard, 2013). They are also considered excellent bioindicators, as the presence or absence of specific groups is strongly correlated with various environmental characteristics, such as temperature and availability of resources. Therefore, changes in the environment can promote significant changes in the composition of the ant community in a certain area (Andersen, 2003). In Brazil, around 1,500 species belonging to 111 genera have been recorded so far; nine of these genera are endemic to the country (AntWiki, 2017). Despite these numbers, the global richness of ant species is probably severely underestimated, especially when poorly-explored Neotropical areas are taken into account (Lattke, 2003).

Among Neotropical countries, Brazil stands out for occupying an extensive area and for having a large number of biomes with unique floral and faunal attributes (Brandão et al., 2006). However, few diversity studies have been conducted on Brazilian ecosystems that have a restricted geographical range. Despite the presence of large forest biomes in the country, grasslands, savannas, shrublands and open woodlands cover large extensions of land in at least four of the six Brazilian biomes. These environments hold a unique biodiversity, but are highly neglected concerning conservation policies and protection when compared to forest ecosystems (Overbeck et al., 2015).

Natural areas of shrublands and grasslands, known as Campos, are widespread over the Southern states of Brazil. In the last years, only a few number of ant surveys were conducted in the Brazilian southern grasslands, all in the state of Rio Grande do Sul (Diehl et al., 2005; Diehl et al., 2014; Albuquerque \& Diehl, 2009; Rosado et al., 2012). Diehl et al. (2005) found 60 species in a sampling expedition to three habitats within Itapuã State Park, a coastal area with sandy soil. In the inventory carried out by Albuquerque \& Diehl (2009), 32 species were recorded using several sampling methods (active sampling, baits and pitfall traps) in eight grassland regions surrounding the Aparados da Serra National Park. Rosado et al. (2012) recorded 72 species using pitfall traps in 
60 sampling points in each of three different grassland areas. The most recent comprehensive inventory of ant diversity in Rio Grande do Sul compiled data from 13 collection sites, including all the different physiognomies found in the state (Diehl et al., 2014) and five sampling methods: manual sampling, baits, Winkler extractors, pitfall traps, and underground traps.

However, so far, no standardized study has been performed in the grassland areas in the state of Paraná, known as Campos Gerais. The state of Paraná, the northernmost state of Southern Region, includes five large geographic divisions: the coast in the East, escarpments of the crystalline complex, and the first, second, and third plateaus in succession westward (Maack, 1981). The Campos Gerais are located on the second Paraná plateau, characterized by the prevalence of rocky soils, shallow rivers, canyons, craters, and caves, among other associated formations (Melo et al., 2001). The dominant phytophysiognomy consists of open grasslands (campo limpo) interspersed with gallery forests and stands of Araucaria (Maack, 1981). Although the soil is generally exposed, depressed areas are occupied by small woods, where the accumulation of organic matter on the soil supports larger plants (Klein \& Hatschbach, 1971).

Rocha \&Weirich Neto (2007) revealed that most of the Campos Gerais vegetation is secondary, a result of human activity. However, according to Castella \& Britez (2004), some studies suggest there is ongoing floristic regeneration in this area. The Campos Gerais have a long history of human interference, which has gradually reduced the extent and diversity of this environment over the years. However, a few conservation units still remain in this region. Among these is the Guartelá State Park (PEG) (Takeda et al., 2001), located on the left margin of the lapó River canyon, in the municipality of Tibagi. Due to its exceptional natural beauty, this park has great tourism potential and receives a large number of visitors every year.

The region where PEG is located is characterized by a mosaic of different vegetation types and by the presence of a rocky soil that constrains plant establishment and growth. Despite that, a study by Carmo \& Assis (2012) found that forest fragments within the park have a high number of plant species, and a survey of vascular plants deposited in the herbarium of the State University of Londrina found 667 specimens collected between 1987 and 2005, belonging to 61 subfamilies and 243 plant species (Rossetto et al., 2012). In addition, a survey identified 160 species of ferns and lycophytes in PEG, belonging to 54 genera and 19 families (Michelon \& Labiak, 2012). Rossetto et al. (2012) and Michelon \& Labiak (2012) found endemic grassland, Cerrado and Atlantic forest species in PEG, making this region a priority for the conservation of these biomes in Southern Brazil.

To date, no studies have addressed arthropod diversity in the PEG region. Such studies are urgently needed because of the great ecological importance of these organisms. Soil arthropods participate in nutrient cycling by fragmenting and ingesting materials in the leaf litter, interact with many microorganisms, and help decompose and mineralize soil materials (Höfer et al., 2001).
Among soil arthropods, ants are particularly important because they are principally predators, but also help in degrade organic matter and remove seeds, affecting the establishment of plant species (Kaspari et al., 2004; Lewinsohn et al., 2005). In addition, the ant species composition of a given area may be an indicator of the conservation status of that ecosystem, because many ant species have obligatory interactions with plants and other animals (Kaspari \& Majer, 2000; Schultz \& McGlynn, 2000). Ants are also relatively easy to be sampled, which provides quick answers to studies on environmental disturbance (Lewinsohn et al., 2005).

In the PEG region, ant research has great potential to provide a foundation for monitoring and preservation activities, which are urgently needed to reduce the serious degree of environmental degradation of the Campos Gerais of Paraná. With that in mind, we carried out the first inventory of the PEG ant fauna using a number of sampling methods. Our objectives were to generate the first ant list for a Campos Gerais area and to increase the knowledge of the diversity and biological potential of this threatened ecosystem.

\section{MATERIAL AND METHODS}

\section{Study site}

Guartelá State Park (PEG) is located in the municipality of Tibagi, on the second plateau of Paraná state. The park is part of the Área de Proteção Ambiental da Escarpa Devoniana (Devonian Escarpment Environmental Protection Area), with a highly varied topography and mostly shallow soils. Most of the area is covered by grassland physiognomies, with patches of Mixed ombrophilous forest and Cerrado (Veloso et al., 1991). According to Köppen's classification system, the regional climate is $\mathrm{Cfb}$ (humid temperate) with direct influence of Cfa (humid subtropical) (Carmo \& Assis, 2012).

Sampling points were established in three areas with-

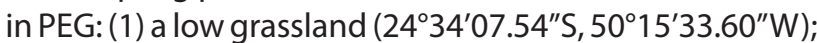
(2) a high grassland $\left(24^{\circ} 34^{\prime} 18.68^{\prime \prime} \mathrm{S}, 50^{\circ} 15^{\prime} 04.72^{\prime \prime} \mathrm{W}\right)$, and (3) a patch of Cerrado (243' $\left.48.18^{\prime \prime} \mathrm{S}, 50^{\circ} 15^{\prime} 14.33^{\prime \prime} \mathrm{W}\right)$. The two grassland areas represent the most common phytophysiognomy of Campos Gerais, the dry grassland (campo seco), defined by the presence of tall or short grasses and small shrubs and rocky outcrops (Moro \& Carmo, 2007). The Cerrado patch is one of the last remnants of the biome in the South of Brazil, along with the Cerrado State Park in the municipality of Jaguariaíva, Paraná. This area is a savanna formation with a semi-continuous herbaceous stratum interrupted only by trees and shrubs, whose growth is directly affected by alternating regional cycles of dry and wet season (Coutinho, 1978).

\section{Collection and processing of samples}

A $400 \mathrm{~m}$ long transect was established in each area, $1 \mathrm{~km}$ apart from the other transects. In each transect, 
20 sampling points were marked $20 \mathrm{~m}$ apart from each other, to ensure independence among samples. At each point, four pitfall traps were installed at each corner of a $2 \mathrm{~m} \times 2 \mathrm{~m}$ grid. Each grid represents a single sample, for a total of 60 samples. Each pitfall trap consisted of a $300 \mathrm{ml}$ plastic cup filled to a third of its volume with a water, salt and detergent solution. Traps were buried so that the opening was level with the soil surface, and exposed for 48 hours. After this period, all biological material was removed from the traps and stored in $80 \%$ ethanol.

We also used Winkler extractors to carry out qualitative samplings of the leaf litter in a Mixed ombrophilous forest area adjacent to the transects. In total, 20 leaf litter samples were collected. In the Winkler technique, $1 \mathrm{~m}^{2}$ areas are defined in the forest soil, the top layer of leaf litter is removed and passed through a sieve, and the resulting material is placed in cloth bags for transportation. The material is then placed in Winkler extractors for 48 hours to extract the fauna (for more details on this technique, see Fisher, 1999). In contrast to the usual technique, we did not fill the collection container of the Winkler extractor with alcohol. Instead, a strip of moist sponge was placed on the bottom, keeping the organisms captured alive. During the 48-hour extraction interval, the collection containers were periodically removed, and the contents were transferred to a white tray. Moving animals in the sieved material were collected while still alive and stored in $80 \%$ ethanol. In addition to pitfall and Winkler sampling, various areas within the park were manually sampled, mostly to capture arboreal ants and cryptic soil species, for a total collection effort of $24 \mathrm{~h}$.

Samples were processed in the Laboratório de Sistemática e Biologia de Formigas da Universidade Federal do Paraná. Ants were separated from other arthropods and identified to the genus level using the identification keys in Baccaro et al. (2015). Whenever possible, ants were identified to the species level by checking the publications cited in Baccaro et al. (2015) and consulting specialists. When species determination was not possible, taxa were treated as morphospecies. Vouchers were deposited in the Padre Jesus Santiago Moure Entomological Collection at the Universidade Federal do Paraná (DZUP).

\section{RESULTS}

In total 163 species were collected, comprising 43 genera and nine subfamilies (Appendix 1). A total of 100 species were identified ( $60.8 \%$ of the total). Based on generic richness, the main subfamily was Myrmicinae (25 genera), followed by Ponerinae (five genera) and Formicinae (four genera) (Table 1). The richest genus was Pheidole, (46 species), followed by Camponotus, (18 species), and Solenopsis, Hypoponera and Crematogaster (eight species each).

The pitfall traps captured 119 species in seven subfamilies and 34 genera. The species with the highest number of records in the pitfall traps was Linepithema micans (Forel, 1908) (Dolichoderinae), with 38 records, followed by Pheidole valens Wilson, 2003 (Myrmicinae), 37
Table 1. Number of genera and species collected by subfamily.

\begin{tabular}{lcc}
\hline \multicolumn{1}{c}{ Subfamily } & Genera & Species \\
\hline Myrmicinae & 25 & 100 \\
Ponerinae & 5 & 16 \\
Formicinae & 4 & 26 \\
Dolichoderinae & 3 & 9 \\
Ectatomminae & 2 & 5 \\
Pseudomyrmecinae & 1 & 4 \\
Proceratiinae & 1 & 1 \\
Amblyoponinae & 1 & 1 \\
Dorylinae & 1 & 1 \\
\hline Total & $\mathbf{4 3}$ & $\mathbf{1 6 3}$ \\
\hline
\end{tabular}

records, and Solenopsis invicta Buren, 1972 (Myrmicinae), 35 records.

From the 119 species collected in pitfall traps 65 were found in the low grassland, 57 in the high grassland, and 103 in cerrado. Eight of these were exclusive to the low grassland, six to the high grassland, and 41 species were found only in Cerrado. The low and high grassland areas shared two species; the low grassland and the Cerrado area shared 13 species; the high grassland and the cerrado, seven species. A total of 42 species were shared between all three transects.

Winkler extractors and active sampling combined yielded 69 recorded species, representing eight subfamilies and 31 genera. Out of the 69 species, 44 were collected only from Winkler extractors and active sampling, while 25 species had already been recorded through pitfall traps.

Five genera found in the present study were recorded for the first time in the state of Paraná (Forelius, Kalathomyrmex, Mycetarotes, Ochetomyrmex and Centromyrmex). Centromyrmex and Kalathomyrmex are also first records for the South Region of Brazil. In total, 28 species represent new records for Paraná state (Appendix 1), out of these, 17 were also recorded for the first time in the South Region of Brazil. In addition, Dorymyrmex paranensis Santschi, 1922, Pheidole pampana Santschi, 1929 and Pheidole breviseta Santschi, 1919 were recorded in Brazil for the first time.

\section{DISCUSSION}

The number of ant species found in Guartelá State Park (163) is significant, especially when compared to studies that used similar sampling efforts. For example, Diehl et al. (2014) listed a total richness of 127 ant species in the inventory of Rio Grande do Sul state, fewer than the total recorded in PEG.

It is important to underscore that the relatively high number of species recorded in PEG was only achievable through a combination of different sampling techniques. This diversity of methods is essential to approach the actual number of species in a given area, since many variables affect the niches occupied by species and their distribution throughout the environment, such as resource availability and competition (Pulliam, 2000; Albrecht 
\& Gotelli, 2001). Ants, in particular, can occupy a wide range of habitats, from arboreal to below-ground strata (Romero \& Jaffé, 1989; Bestelmeyer et al., 2000; Camacho \& Vasconcelos, 2016).

The pitfall trap was the quantitative method responsible for the largest number of epigaeic species recorded in the present study. Winkler extractors were almost exclusively responsible for sampling specialized species within the leaf litter, while most arboreal and specialized predator species were collected through active sampling. Although active sampling and Winkler extractors were used qualitatively in this study, they were extremely important as supplementary methods to obtain a more complete inventory of the local ant fauna, given the number of species collected exclusively through these methods (44).

Among the subfamilies collected the dominance of Myrmicinae, Formicinae, and Ponerinae was already expected, because these are the largest Formicidae subfamilies and have high local species richness in the Neotropical region (Ward, 2014). In fact, these three subfamilies together represent $83 \%$ of the total known diversity of ants.

The prevalence of Pheidole species in the samples was also predictable, since this genus is considered hyperdiverse and ubiquitous (Wilson, 2003). Despite this, the 46 Pheidole species recorded in PEG still represented a surprisingly large number, given the geographic extension of the park and the fact that habitat heterogeneity in grassland areas is not as great as in forests, for instance. The genus Camponotus, also hyperdiverse and ubiquitous with generalist habits and high colonization success, was well-represented in PEG samples, with 18 recorded species.

Although Myrmicinae, Formicinae, and Ponerinae were generally prevalent, the species with the highest number of records was Linepithema micans (Dolichoderinae), a generalist ant that may occupy different phytophysiognomies. This is the most common ant species in vineyards of Southern Brazil (Sacchett et al., 2009), and it is considered the main disseminator of the land-pearl, Eurhizococcus brasiliensis (Hempel, 1922), a hemipteran in the Margarodidae family that is considered a pest of grapevines (Hickel et al., 2001).

In the present work, we noticed a scarcity of army ants (Dorylinae), known for their massive foraging habits, nomadic behavior, and lack of permanent nests (Brady, 2003). The only specimen of this group of ants in our samples belonged to Neivamyrmex diana (Forel, 1912). Neivamyrmex ant colonies have thousands of individuals, which have a partial or predominantly subterranean habit and form long foraging columns. These ants are specialized predators of other ant colonies, and forage as a group (Brady, 2003). The dearth of army ants in our samples reflects the fact that this group is primarily found in structurally more heterogeneous physiognomies, such as forests, and are usually less diverse and harder to observe in open fields and savannas (Baccaro et al., 2015). However, this result can also be due to short sampling period (see O'Donnell et al., 2007).
There was a low degree of species overlap between the three sampled areas, and a high number of exclusive species in the Cerrado transect. This may reflect significant differences in habitat structure between areas, particularly between the two grassland areas and the patch of Cerrado, because the latter has a denser and more heterogeneous shrub layer that support the establishment of a larger number of species (Campos et al., 2008).

One of the main results of the present study was the detection and addition of many new taxa to the ant fauna of Paraná state, the Southern of Brazil, and even for Brazil as a whole. The new records for the state belonged to genera Forelius (Dolichoderinae), Centromyrmex (Ponerinae), Kalathomyrmex, Mycetarotes, and Ochetomyrmex (Myrmicinae).

Neotropical species in the genus Forelius nest in the ground, in open areas without of vegetation. Nests often have a layer of loose soil by the entrance, and there is usually more than one nest per colony. Because these ants have high thermal tolerance, they are typically active during the hottest times of the day. Workers move quickly and forage primarily on soil arthropods and, in some cases, on honeydew accumulated on the vegetation (Cuezzo, 2000). Centromyrmex is a cosmopolitan Ponerinae genus with a mostly tropical distribution, easily recognized by the presence of spiniform setae on the mesotibiae. Species in this genus are obligatory predators of termites and have subterranean habits, nesting in cavities inside their prey's nests. Colonies are usually relatively small (Kempf, 1967). The cryptic habit and the low local abundance make it rare for ant inventories to detect species of this genus. Kalathomyrmex is a monotypic fungus-farming ant genus found exclusively in South America. Nests are usually built in sandy soils and can endure long flood periods. As a result, they are very common in riverbanks across many regions of Brazil (Klingenberg \& Brandão, 2009). Mycetarotes, another genus of fungus-farming ants, is exclusively Neotropical. Species have small colonies of 100-350 individuals that live in underground nests with a narrow opening bordered by a small mound of dirt (Mayhé-Nunes, 1995). Ochetomyrmex includes only two species, and little is known about them. They are probably epigaeic generalist predators, found in elevations between $100 \mathrm{~m}$ and 1,300 $\mathrm{m}$ in the central-northern region of South America (Fernández, 2003).

The results from this study represent an advance in Neotropical Myrmecology, especially regarding the knowledge of ant diversity in natural grasslands of Southern Brazil. Considering the anthropogenic pressure over the Campos Gerais, an endemic physiognomy of Paraná, species inventories are clearly important, because only through the knowledge about the local fauna it is possible to develop conservation strategies (Margules \& Pressey, 2000). Through this study, which represents the first formal survey of the ant fauna in a conservation area within the Campos Gerais of Paraná state, we hope to stimulate an increase in the number of studies addressing local diversity, which may reveal priority taxonomic interest groups and therefore provide a foundation for future conservation policies. 


\section{ACKNOWLEDGEMENTS}

We thank Instituto Ambiental do Paraná (IAP, Environmental Institute of Paraná) for issuing a collection permit (№ 23.16 - 07/20/2016) and Mr. Cristovam S. Queiroz, PEG's manager, for supporting our study. We also thank Aline M. de Oliveira for helping with sampling and Luiza F. Luzio for helping with processing of samples. We thank the following specialists in different genera, who confirmed the species listed in this study: Alexandre Casadei Ferreira (Pheidole), Lina Maria Pedraza (Crematogaster), Mayrón Escárraga (Linepithema), and Thiago S. Ranzani da Silva (Strumigenys). This work was supported by the Brazilian Council of Research and Scientific Development (CNPq grant 459353/2014-4). Finally, WF and RF thank the CNPq for the grants $130642 / 2016-9$ and 302462/2016-3, respectively.

\section{REFERENCES}

Albrecht, M. \& Gotelli, N.J. 2001. Spatial and temporal niche partitioning in grassland ants. Oecologia, 126: 134-141.

Albuquerque, E.Z. \& Diehl, E. 2009. Análise faunística das formigas epígeas (Hymenoptera: Formicidae) em campo nativo no planalto das Araucárias, Rio Grande do Sul. Revista Brasileira de Entomologia, 53(3): 398-403.

Andersen, A.N. 2003. Ant biodiversity in arid Australia: productivity, species richness and community organization. Records of the South Australian Museum Monograph Series, 7: 79-92.

AntWiki. 2017. Available at: www.antwiki.org/wiki/Welcome to AntWiki. Access in: 31/08/2017.

Baccaro, F.B.; Feitosa, R.M.; Fernandez, F.; Fernandes, I.0.; Izzo, T.J.; Souza, J.P. de \& Solar, R. 2015. Guia para os gêneros de formigas do Brasil. Manaus, Editora INPA. 388p.

Bestelmeyer, B.T.; Agosti, D.; Alonso, L.E.; Brandão, C.R.F.; Brown Jr., W.L.; Delabie, J.H.C. \& Silvestre, R. 2000. Field techniques for the study of ground-dwelling ants: an overview, description, and evaluation. In: Agosti, D.D.; Majer, J.D.; Alonso, L.E. \& Schultz, T.R. (Eds.). Ants: Standard Methods for Measuring and Monitoring Biodiversity. Washington, Smithsonian Institution Press. p. 122-144.

Brady, S.G. 2003. Evolution of the army ant syndrome: the origin and longterm evolutionary stasis of a complex of behavioral and reproductive adaptations. Proceedings of the National Academy of Sciences of the United States of America, 100: 6575-6579.

Brandão, C.R.F.; Cancello, E.M.; Yamamoto, C.I. \& Scott-Santos, C. 2006. Invertebrados Terrestres. In: Lewinsohn, T. (Org.). Avaliação do estado do conhecimento da biodiversidade brasileira. Brasília, Ministério do Meio Ambiente. p. 205-269. (Série Biodiversidade, 15).

Camacho, G.P. \& Vasconcelos, H.L. 2016. Ants of the Panga Ecological Station, a Cerrado reserve in central Brazil. Sociobiology, 62(2): 281-295.

Campos, R.I.; Lopes, C.T.; Magalhães, W.C.S. \& Vasconcelos, H.L. 2008. Vertical stratification of ants in savanna vegetation in the Serra de Caldas Novas State Park, Goias, Brazil. Iheringia Serie Zoologia, 98: 311-316.

Carmo, M.R.B. \& Assis, M.C. 2012. Caracterização florística e estrutural das florestas naturalmente fragmentadas no Parque Estadual do Guartelá, município de Tibagi, estado do Paraná. Acta Botânica Brasilica, 26: 133-135.

Castella, P.R. \& Britez, R.M.A. 2004. Floresta de Araucária no Paraná Conservação e diagnóstico dos remanescentes florestais. Fundação de Pesquisas Florestais do Paraná, Brasília, p. 236.
Coutinho, L.M. 1978. 0 conceito de cerrado. Revista Brasileira de Botânica, 1(1): $17-23$

Cuezzo, F. 2000. Revisión del género Forelius (Hymenoptera: Formicidae: Dolichoderinae). Sociobiology, 35: 197-275.

Davidson, D.W.; Cook, S.C.; Snelling, R.R. \& Chua, T.H. 2003. Explaining the abundance of ants in lowland tropical rainforest canopies. Science, 300: 969-972.

Diehl, E.; Diehl-Fleig, E.; Albuquerque, E.Z. \& Junqueira, L.K. 2014. Richness of termites and ants in the State of Rio Grande do Sul, Southern Brazil. Sociobiology, 61(2): 145-154.

Diehl, E.; Sacchet, F. \& Albuquerque, E.Z. 2005. Riqueza de formigas de solo, na Praia da Pedreira, Parque Estadual de Itapuã, Viamão, RS, Brasil. Revista Brasileira de Entomologia, 49(4): 552-556.

Fernández, C.F. 2003. Myrmicinae ants of the genera Ochetomyrmex and Tranopelta (Hymenoptera: Formicidae). Sociobiology, 41: 633-661.

Fisher, B.L. 1999. Improving inventory efficiency: a case study of leaf-litter ant diversity in Madagascar. Ecological Applications, 9(2): 714-731.

Guénard, B. 2013. An overview of the species and ecological diversity of ants. Encyclopedia of Life Sciences, 1-10. Available at: http://onlinelibrary. wiley.com/doi/10.1002/9780470015902.a0023598/pdf. Access in: 20/12/2017.

Hickel, E.R.; Peruzzo, E.L. \& Schuck, E. 2001. Controle da pérola-da-terra, Eurhizococcus brasiliensis (Hempel) (Homoptera: Margarodidae), através da insetigação. Neotropical Entomology, 30(1): 127-132.

Höfer, H.; Hanagarth, W.; Garcia, M.; Martius, C.; Franklin, E.; Rombke, J. \& Beck, L. 2001. Structure and function of soil fauna communities in Amazonian anthropogenic and natural ecosystems. Euro Journal Soil Biology, 37: 229-235.

Kaspari, M. \& Majer, J.D. 2000. Using ants to monitor environmental change. In: Agosti, D.D.; Majer, J.D.; Alonso, L.E. \& Schultz, T.R. (Eds.). Ants: standard methods for measuring and monitoring biodiversity. Washington, Smithsonian Institution Press. p. 89-98.

Kaspari, M.; Ward, P.S. \& Yuan, M. 2004. Energy gradients and the geographic distribution of local ant diversity. Oecologia, 140: 407-413.

Kempf, W.W. 1967. A synopsis of the Neotropical ants of the genus Centromyrmex Mayr (Hymenoptera: Formicidae). Studia Entomologica, 9: 401-410.

Klein, R.M. \& Hatschbach, G. 1971. Fitofisionomia e notas complementares sobre o mapa fitogeográfico de Quero-Quero (Paraná). Boletim Paranaense de Geociências, 28-29: 159-188.

Klingenberg, C. \& Brandão, C.R.F. 2009. Revision of the fungus-growing ant genera Mycetophylax Emery and Paramycetophylax Kusnezov rev. stat. and description of Kalathomyrmex n. gen. Zootaxa, 31: 1-31.

Lattke, J.E. 2003. Biogeografía de las hormigas neotropicales. In: Fernández, F. (Ed.). Introducción a las hormigas de la región Neotropical. Bogotá, Instituto de Investigación de Recursos Biológicos Alexander von Humboldt. p. 65-85.

Lewinsohn, T.M.; Freitas, A.V.L. \& Prado, P.I. 2005. Conservation of terrestrial invertebrates and their habitats in Brazil. Conservation Biology, 19: 640-645.

Maack, R. 1981. Geografia física do Estado do Paraná. Rio de Janeiro, Livraria José Olympio. 442p.

Margules, C.R. \& Pressey, R.L. 2000. Systematic conservation planning. Nature, 405: 243-253.

Mayhé-Nunes, A.J. 1995. Sinopse do gênero Mycetarotes (Hym., Formicidae), com a descrição de duas espécies novas. Boletin de Entomología Venezolana, 10(2): 197-205.

Melo, M.S.; Moro, R.S. \& Guimarães, G.B. 2001. Os Campos Gerais do Paraná. In: Melo, M.S.; Moro, R.S. \& Guimarães, G.B. (Eds.). Patrimônio natural dos Campos Gerais do Paraná. Ponta Grossa, UEPG. p. 18-22. 
Michelon, C. \& Labiak, P.H. 2012. Samambaias e licófitas do Parque Estadual do Guartelá, Paraná. In: Carpanezzi, 0.T.B.; Campos, J.B. (Orgs.). Coletânea de pesquisas parques estaduais de Vila Velha, Cerrado e Guartelá. Curitiba, Instituto Ambiental do Paraná. p. 337-345.

Moro, R.S. \& Carmo, M.R.B. 2007. A vegetação campestre nos Campos Gerais. In: Melo, M.S.; Moro, R.S. \& Guimarães, G.B. (Eds.). Patrimônio natural dos Campos Gerais do Paraná. Ponta Grossa, UEPG. p. 93-98.

0'Donnell, S.; Lattke, J.; Powell, S. \& Kaspari, M. 2007. Army ants in four forests: geographic variation in raid rates and species composition. Journal of Animal Ecology, 76: 580-589.

Overbeck, G.E.; Vélez-Martin, E.; Scarano, F.R.; Lewinsohn, T.M.; Fonseca, C.R.; Meyer, S.T.; Müller, S.C.; Ceotto, P.; Dadalt, L.; Durigan, G.; Ganade, G.; Gossner, M.M.; Guadagnin, D.L.; Lorenzen, K.; Jacobi, C.M.; Weisser, W.W. \& Pillar, V.D. 2015. Conservation in Brazil needs to include non-forest ecosystems. Diversity and Distributions, 21: 1455-1460.

Pulliam, H.R. 2000. On the relationship between niche and distribution. Ecology Letters, 3: 349-361.

Rocha, C.H. \& Weirich Neto, P.H. 2007. Origem dos sistemas de produção e fragmentação da paisagem nos Campos Gerais. In: Melo, M.S.; Moro, R.S. \& Guimarães, G.B. (Eds.). Patrimônio natural dos Campos Gerais do Paraná. Ponta Grossa, UEPG. p. 171-180.

Romero, H. \& Jaffé, K. 1989. A comparison of methods for sampling ants (Hymenoptera: Formicidae) in savannas. Biotropica, 21: 348-352.

Rosado, J.L.0.; Gonçalves, M.G. de; Dröse, W.; Silva, E.J.E.; Krüger, R.F.; Feitosa, R.M. \& Loeck, A.E. 2012. Epigeic ants (Hymenoptera: Formicidae) in vineyards and grassland areas in the Campanha region, state of Rio Grande do Sul, Brazil. Checklist, 8: 1184-1189.

Rossetto, E.F.S.; Ferreira Junior, M.; Aguiar, T.H. \& Vieira, A.0.S. 2012. 0 Parque Estadual do Guartelá (Tibagi, PR): Avaliação do acervo das espécies vasculares do herbário da Universidade Estadual de Londrina. In: Carpanezzi, 0.T.B. \& Campos, J.B. (Orgs.). Coletânea de pesquisas parques estaduais de Vila Velha, Cerrado e Guartelá. Curitiba, Instituto Ambiental do Paraná. p. 239-336.

Sacchett, F.; Botton, M. \& Diehl, E. 2009. Ant species associated with the dispersal of Eurhizococcus brasiliensis (Hempel in Wille) (Hemiptera: Margarodidae) in vineyards of the serra gaucha, Rio Grande do Sul, Brazil. Sociobiology, 54: 943-954.

Schultz, T.R. \& McGlynn, T.P. 2000. The interactions of ants with other organisms. In: Agosti, D.D.; Majer, J.D.; Alonso, L.E. \& Schultz, T.R. (Eds.). Ants: standard methods for measuring and monitoring biodiversity. Washington, Smithsonian Institution Press. p. 35-44.

Takeda, A.K.; Janete, I.; Takeda, M. \& Farago, P.V. 2001. Unidades de conservação da região dos Campos Gerais, Paraná/Conservation units of the Campos Gerais Region, Paraná. Publicatio UEPG - Biological and Health Sciences, 7: 57-78.

Veloso, H.P.; Filho, A.L.R.R. \& Lima, J.C.A. 1991. Classificação da vegetação brasileira, adaptada a um sistema universal. Rio de Janeiro, IBGE. 123p.

Ward, P.S. 2007. Phylogeny, classification, and species-level taxonomy of ants (Hymenoptera: Formicidae). Zootaxa, 563: 549-563.

Ward, P.S. 2014. The phylogeny and evolution of ants. Annual Review of Ecology, Evolution and Systematics, 45: 23-43.

Wilson, E.0. \& Hölldobler, B. 2005. Eusociality: origin and consequences: Correction. Proceedings of the National Academy of Science, 102: 13367-13371.

Wilson, E.0. 2003. Pheidole in the New World. Cambridge, Harvard University Press. 794p. 


\section{APPENDIX 1}

Species recorded in Guartelá State Park. LG - low grassland; HG - high grassland; CE - Cerrado; FO - forest (leaf litter). * First record for Paraná, + First record for the Southern Brazil; \# First record for Brazil.

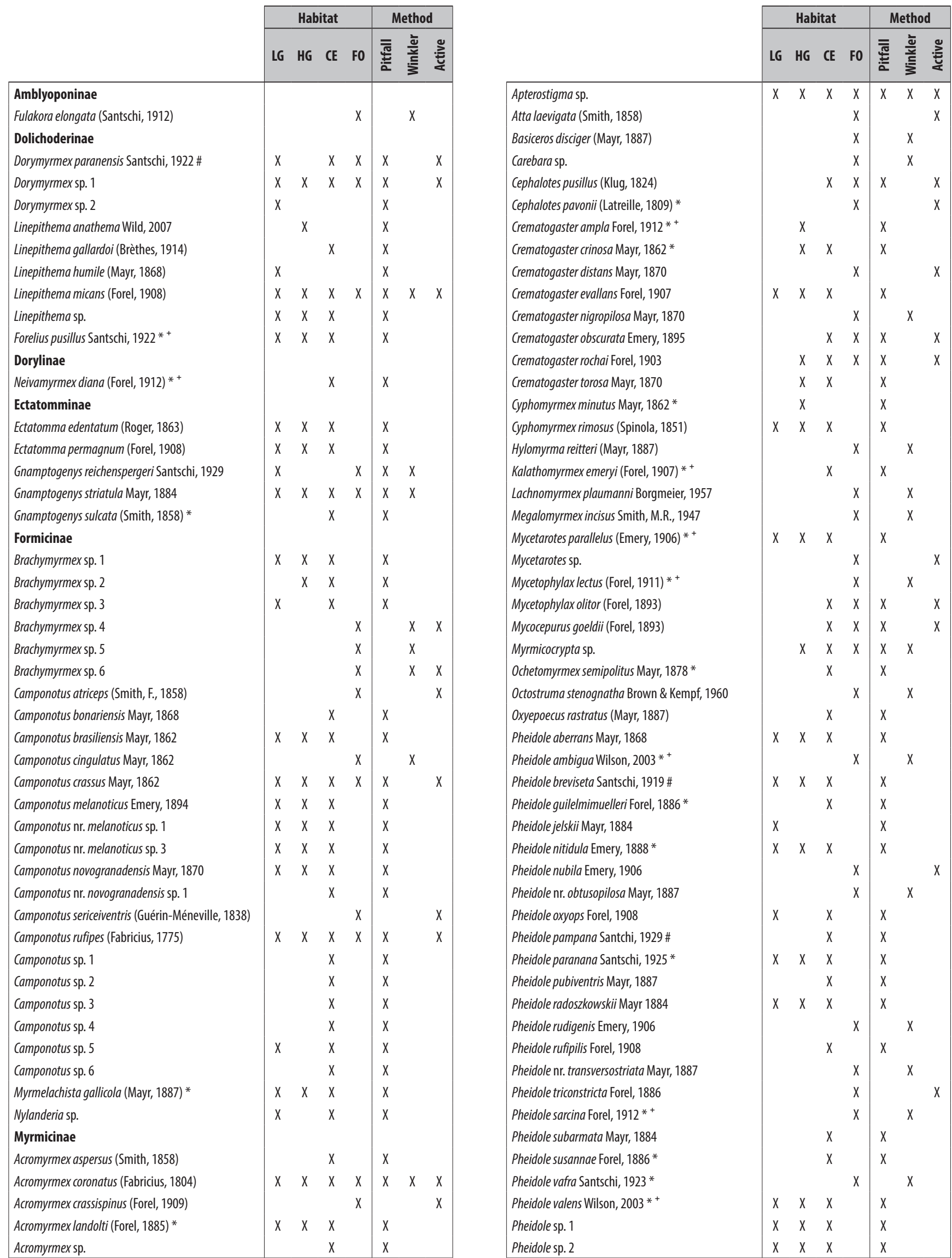




\section{\begin{tabular}{|l|l|} 
Habitat & Method \\
\hline
\end{tabular} \\ LG HG CE FO 壱 竞 冚}

Pheidole sp. 3

Pheidole sp. 4

Pheidole sp. 5

Pheidole sp. 6

Pheidole sp. 7

Pheidole sp. 8

Pheidole sp. 9

Pheidole sp. 10

Pheidole sp. 11

Pheidole sp. 12

Pheidole sp. 13

Pheidole sp. 14

Pheidole sp. 15

Pheidole sp. 16

Pheidole sp. 17

Pheidole sp. 18

Pheidole sp. 19

Pheidole sp. 20

Pheidole sp. 21

Pheidole sp. 30

Pheidole sp. 31

Pheidole sp. 32

Pogonomyrmex naegelli Forel, 1878

Solenopsis invicta Buren, 1972

Solenopsis sp. 1

Solenopsis sp. 2

Solenopsis sp. 3

Solenopsis sp. 4

Solenopsis sp. 5

Solenopsis sp. 7

Solenopsis sp. 8

Strumigenys epinotalis Weber, 1934 *+

Strumigenys infidelis Santischi, 1919

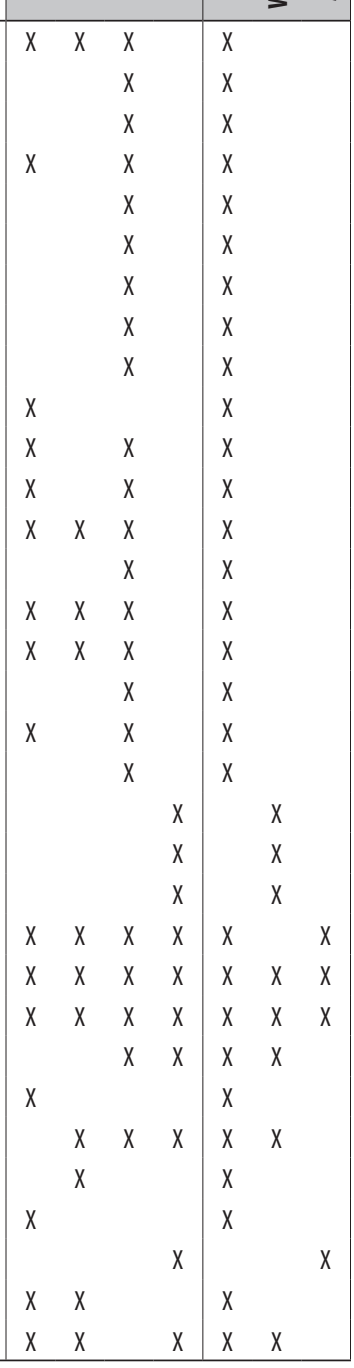

Method

Strumigenys louisianae Roger, 1863

Strumigenys crassicornis Mayr, 1887

Strumigenys abditivata (Bolton, 2000)

Trachymyrmex holmgreni Wheeler, W.M., 1925

Trachymyrmex sp. 1

Trachymyrmex sp. 2

Wasmannia auropunctata (Roger, 1863)

Wasmannia affinis Santschi, 1929

Wasmannia lutzi Forel, 1908

Ponerinae

Centromyrmex brachycola (Roger, 1861) *

Hypoponera foreli (Mayr, 1887)

Hypoponera sp. 1

Hypoponera sp. 2

Hypoponera sp. 4

Hypoponera sp. 5

Hypoponera sp. 6

Hypoponera sp. 7

Hypoponera sp. 8

Neoponera marginata (Roger, 1861)

Neoponera verenae Forel, 1922

Odontomachus chelifer (Latreille, 1802)

Odontomachus haematodus (Linnaeus, 1758)

Odontomachus meinerti (Forel 1905)

Pachycondyla harpax (Fabricius, 1804)

Pachycondyla striata Smith, 1858

\section{Proceratiinae}

Discothyrea sexarticulata Borgmeier, 1954

Pseudomyrmecinae

Pseudomyrmex simplex (Smith, F., 1877) *+

Pseudomyrmex termitarius (Smith, 1885)

Pseudomyrmex sp. 3

Pseudomyrmex sp. 4
LG HG CE FO

言 产

\begin{tabular}{|c|c|c|c|c|c|c|}
\hline & & & $X$ & & $X$ & \\
\hline & & & $X$ & & $X$ & \\
\hline & & & $x$ & & $X$ & \\
\hline$X$ & $X$ & $X$ & & $X$ & & \\
\hline$X$ & $X$ & $X$ & & $X$ & & \\
\hline & & & $x$ & & $X$ & \\
\hline$X$ & $X$ & $X$ & & $X$ & & \\
\hline$X$ & & $X$ & & $X$ & & \\
\hline$x$ & & $x$ & $x$ & $x$ & $x$ & $x$ \\
\hline & $x$ & $x$ & & $x$ & & \\
\hline & & & $X$ & & $X$ & \\
\hline & $x$ & & & $x$ & & \\
\hline & $X$ & & $X$ & $X$ & $X$ & \\
\hline & & & $X$ & & $X$ & \\
\hline & & & $X$ & & $X$ & \\
\hline & & & $X$ & & $X$ & \\
\hline & & & $X$ & & $X$ & \\
\hline & & & $X$ & & $X$ & $X$ \\
\hline & & $X$ & $X$ & $X$ & & $X$ \\
\hline$X$ & $X$ & $X$ & $X$ & $X$ & & $X$ \\
\hline & & $X$ & & $X$ & & \\
\hline$X$ & & $x$ & & $X$ & & \\
\hline & & $X$ & & $X$ & & \\
\hline & & $x$ & & $X$ & & \\
\hline$X$ & $X$ & $x$ & & $X$ & & \\
\hline & & & $x$ & & $x$ & \\
\hline$x$ & & $x$ & & $x$ & & \\
\hline & & $X$ & & $x$ & & \\
\hline$X$ & & & & $X$ & & \\
\hline & & & $x$ & & & $X$ \\
\hline
\end{tabular}

